\title{
Rearing technique and demographic parameters of Tetrastichus giffardianus Silvestre (Hymenoptera: Eulophidae)
}

\section{Técnica de criação e parâmetros demográficos de Tetrastichus giffardianus Silvestre (Hymenoptera: Eulophidae)}

\author{
Elania Clementino Fernandes ${ }^{1 *}$; Mariana Macêdo Souza ${ }^{2}$; Maria Itala Alves \\ Souza $^{3}$; Antonio Gabriel Nunes Felipe ${ }^{4}$; Elton Lucio Araujo ${ }^{5}$
}

\begin{abstract}
Tetrastichus giffardianus Silvestri (Hymenoptera: Eulophidae) is a gregarious koinobiont endoparasitoid of frugivorous dipterans. In recent years, T. giffardianus has been detected parasitizing Ceratitis capitata (Wiedemann) (Diptera: Tephritidae) in different Brazilian semiarid sites. Thus, T. giffardianus has potential to be used in the biological control of $C$. capitata in semi-arid conditions. However, one of the factors limiting the use of this parasitoid is the lack of detailed information on rearing methods and bioecological aspects. Thus, the main objectives of this study were to demonstrate a rearing technique for T. giffardianus and to determine its population increase potential in laboratory. For this specimens of T. giffardianus were obtained in the field through of the collection of chestnut fruits (Terminalia catappa L. - Combretaceae) infested with C. capitata. The specimens obtained were used to adapt a rearing methodology for $T$. giffardianus under laboratory conditions (temperature: $25 \pm 2^{\circ} \mathrm{C}$; relative humidity: $60 \pm 10 \% ; 12 \mathrm{~h}$ photophase). Information on demographic parameters for a $T$. giffardianus population was obtained using the same methodology. Based on the parameters evaluated, we found that the intrinsic rate of population increase of $T$. giffardianus was 0.34 , the average time of one generation was 19.7 days, the population doubling time was 2.03 days and the finite rate of population increase $(\lambda)$ was 1.41. The demographic parameters obtained demonstrated that, with the rearing technique used, it is possible to maintain populations of T. giffardianus and enable them to multiply in laboratory.
\end{abstract}

Key words: Tephritidae. Parasitoid. Biological control.

\section{Resumo}

Tetrastichus giffardianus Silvestri (Hymenoptera: Eulophidae) é um endoparasitoide coinobionte gregário de dípteros frugívoros. Nos últimos anos, T. giffardianus tem sido detectado parasitando Ceratitis capitata (Wiedemann) (Diptera: Tephritidae) em diferentes locais do semiárido brasileiro. Assim, T. giffardianus tem potencial para ser utilizado no controle biológico de $C$. capitata nas condições do semiárido. Entretanto, um dos fatores limitantes para uso deste parasitoide é a falta de informações detalhadas sobre sua metodologia de criação e seus aspectos bioecológicos. Portanto, o

${ }^{1}$ Dr $^{\mathrm{a}}$ em Fitotecnia, Universidade Federal Rural do Semi-Árido, UFERSA, Mossoró, RN, Brasil. E-mail: elania.fernandes@ ufersa.edu.br

2 Discente de Mestrado, Programa de Pós-Graduação em Entomologia, Universidade Federal de Lavras, UFLA, Lavras, MG, Brasil. E-mail: mari.macedo.dsouza@gmail.com

3 Discente de Mestrado, Programa de Pós-Graduação em Agronomia, Universidade Federal da Paraíba, UFPB, Centro de Ciências Agrárias, Campus II, Areia, Brasil. E-mail: itala.alves@hotmail.com

4 Discente de Agronomia, Centro de Ciências Agrárias, UFERSA, Mossoró, RN, Brasil. E-mail: gabrielfelipe1221@hotmail.com

5 Prof., Universidade Federal Rural do Semi-Árido, UFERSA, Mossoró, RN, Brasil. E-mail: elton@ufersa.edu.br

* Autor for correspondence 
principal objetivo deste estudo foi demonstrar uma técnica de criação para T. giffardianus e determinar seu potencial de crescimento populacional, em laboratório. Para isto, espécimens de T. giffardianus foram obtidos em campo, através da coleta de frutos de castanhola (Terminalia catappa - Combretaceae) infestados com C. capitata. Os exemplares obtidos foram utilizados para adaptar uma metodologia de criação para T. giffardianus em condições de laboratório (temperatura de $25 \pm 2^{\circ} \mathrm{C}$, umidade relativa de $60 \pm 10 \%$ e fotofase de 12 horas). As informações sobre os parâmetros demográficos para uma populacional de $T$. giffardianus foram obtidas usando a mesma metodologia. Com base nos parâmetros avaliados foi constatado que a taxa intrínseca de aumento populacional de T. giffardianus foi de $0,34, \mathrm{o}$ tempo médio de uma geração foi de 19,7 dias, o tempo de duplicação da população foi de 2,03 dias e a taxa finita de aumento populacional $(\lambda)$ foi de 1,41 . Os parâmetros demográficos obtidos demonstraram que, com a técnica de criação utilizada, é possível manter populações de T. giffardianus e multiplicá-las em laboratório.

Palavras-chave: Tephritidae. Parasitoide. Controle biológico.

\section{Introduction}

Tetrastichus

giffardianus

Silvestri (Hymenoptera: Eulophidae) is a gregarious koinobiont endoparasitoid of fruit flies (Diptera: Tephritidae). T. giffardianus females enter cracked fruits to oviposit directly into the larvae of frugivorous dipterans (PURCELL et al., 1996).

Due to its beneficial characteristics as a parasitoid of fruit flies, $T$. giffardianus was transported from West Africa to Hawaii (USA) and later distributed to several Latin American countries for the control of Ceratitis capitata (Wiedemann) (Diptera: Tephritidae) (OVRUSKI et al., 2000; PURCELL et al., 1996). In Brazil, T. giffardianus was introduced in the state of São Paulo, Southeast Brazil in 1932 to control C. capitata in citrus orchards (COSTA et al., 2005).

Although successful in different parts of the world, T. giffardianus failed in São Paulo, possibly because the species did not adapt to the climatic conditions. However, after 60 years with no reports of its presence in Brazil, T. giffardianus was recorded as parasitizing fruit flies at different sites in the Northeast region of the country (ARAUJO et al., 2015; ARAÚJO et al., 2016; COSTA et al., 2005), where a semi-arid climate predominates, similar to the center of origin of this parasitoid. In the northeastern region of Brazil, C. capitata was detected for the first time in 1991 and currently is an important pest, infesting different types of fruits (ARAUJO et al., 2013).

Despite the diversity of fruit fly parasitoids previously reported in Northeast Brazil (ZUCCHI et al., 2012), few of them have the potential for use in the biological control of $C$. capitata. Thus, $T$. giffardianus can be a viable option to the biological control of $C$. capitata in Northeast Brazil.

However, one of the limiting factors for the use of parasitoids in biological control programs is the possibility of their rearing in laboratory. Maintaining natural enemies and facilitating their multiplication in laboratory have been some of the great challenges of biological control (PARRA, 2014). However, it is through laboratory rearing that it is possible to obtain basic biological information concerning the use of these natural enemies (CANCINO et al., 2009).

Some information about the T. giffardianus rearing was presented by Purcell et al. (1996). However, more detailed information is lacking which could enable continuous and standardized rearing of $T$. giffardianus to be established. Furthermore, information on population demographics of this parasitoid is scarce. Therefore, the objectives of this study were to demonstrate a rearing technique for T. giffardianus under laboratory condition (temperature: $25 \pm 2^{\circ} \mathrm{C}$; relative humidity: 60 $\pm 10 \% ; 12 \mathrm{~h}$ photophase) and determine the demographic parameters of a population reared 
using this technique, in order to ascertain whether this methodology is adequate for maintaining populations of this parasitoid and enabling them to multiply.

\section{Material and Methods}

The bioassays were carried out in climatized rooms under the following conditions (temperature: $25 \pm 2{ }^{\circ} \mathrm{C}$; relative humidity: $60 \pm 10 \%$; photophase: $12 \mathrm{~h})$ at the Applied Entomology Laboratory of the Universidade Federal Rural do Semi-Árido, Mossoró, Rio Grande do Norte, Brazil (5'11'26" S and $37^{\circ} 20$ ' $17^{\prime \prime} \mathrm{W}$; altitude: $20 \mathrm{~m}$ ).

\section{Rearing technique for T. giffardianus}

To establish T. giffardianus, chestnut fruits (Terminalia catappa L. - Combretaceae) infested with $C$. capitata were collected in the city of Mossoró (RN). Previous studies demonstrated T. giffardianus parasitizing C. capitata in fruits of chestnut and guava (Psidium guajava L.) in Mossoró. The fruits were placed in paper bags and taken to the laboratory where they were placed in plastic trays containing a layer of vermiculite and covered with voile cloth. After seven days, the vermiculite was sieved to obtain the puparia. These were transferred to Petri dishes containing a layer of moist vermiculite where they remained until the emergence of adults (flies or parasitoids).

Adults $T$. giffardianus obtained were placed in a cage $(30 \times 30 \times 30 \mathrm{~cm})$ with an opening $(10 \times$ $10 \mathrm{~cm}$ ) in the upper part covered by voile cloth to allow aeration (Figure 1A). The parasitoids were fed with granulated sugar $(3 \mathrm{~g})$ provided in a Petri dish $(5 \mathrm{~cm}$ diameter $\times 0.5 \mathrm{~cm}$ high) and pure honey $(1 \mathrm{ml})$ brushstroke in a paper filter. The water was supplied by a $50 \mathrm{ml}$ plastic bottle with absorbent tape (Spontex $\left.{ }^{\circledR}\right)$.

For multiplication of the parasitoids, each day chestnut fruits were manually infested with third instar larvae ( \pm 10 days) of laboratory-reared $C$. capitata (Figure 1B). The infested fruits were packed in $1000 \mathrm{ml}$ transparent plastic containers (15 $\mathrm{cm}$ diameter $\times 9.4 \mathrm{~cm}$ high) (Figure 1C) and offered to the parasitoids (Figure 1D). After exposure for $24 \mathrm{~h}$, the fruits were transferred to plastic containers containing moist vermiculite to obtain the pupae (Figure 1E). The pupae were placed in Petri dishes ( $9.0 \mathrm{~cm}$ diameter $\times 1.5 \mathrm{~cm}$ height) which were then sealed with plastic film. The pupae remained in the Petri dishes until the emergence of parasitoids (Figure 1F) which were released daily into the rearing cages. 
Figure 1. Rearing of Tetrastichus giffardianus in the laboratory. Adult rearing cage with food and water containers (A); Infestation of fruits with larvae of Ceratitis capitata (B); Infested fruit inside the plastic container (C); Exposure of fruits to parasitoids (D); Petri dish with pupae on moist vermiculite (E); Adults parasitoids (female and male) (F).

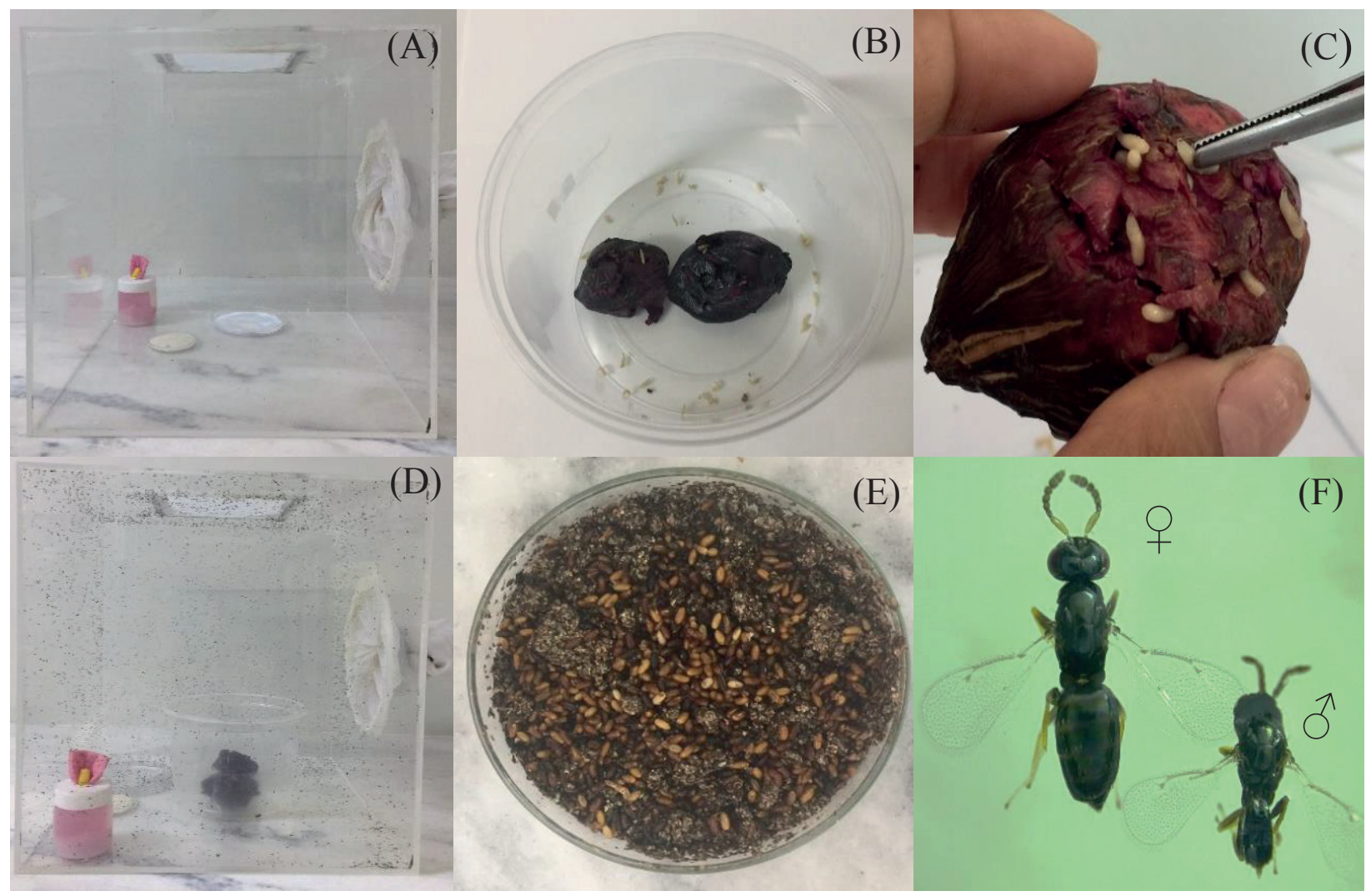

\section{Demographics of T. giffardianus population}

The bioassay involved a $T$. giffardianus population that had been maintained in the laboratory for about 28 generations. Newly emerged males and females ( 15 of each) were selected; these were sexed based on the morphological characteristics of the antennas (males have longer antenna than females) and abdomen (males have smaller abdomen than females). The 15 couples were placed together in a cage $(20 \times 20 \times 20 \mathrm{~cm})$ with an opening $(5 \times 5 \mathrm{~cm})$ in the upper part, covered with voile cloth to allow aeration. One of the sides contained a sleeve-shaped screen for manipulation. The parasitoids had access to water, sugar and pure honey ad libitum.

Each day, third instar larvae of C. capitata in chestnut fruits were exposed to parasitism in a cage with 15 couples, at a proportion of seven larvae per female, until the death of the parasitoids. After parasitism, the fruits were placed in containers with vermiculite. The pupae obtained were individually placed in plastic containers (50 $\mathrm{ml}$ volume) containing moistened vermiculite and the containers were then sealed with plastic film. The pupae remained in the containers until the emergence of flies and/or parasitoids.

Ten days after the onset of parasitism, the number of emerged flies and/or parasitoids was evaluated daily. The pupae that remained closed were dissected to verify the presence of flies or parasitoids in order to accurately determine the rate of parasitism. Dissection was performed using scalpel and tweezers under a stereomicroscopic microscope, at a magnification of $80 \times$. 
The following variables were calculated, through the fertility life table based on Silveira Neto (1976): number of offspring (ND), which was obtained by adding the emerged and non-emerged parasitoids; sex ratio (SR), determined using the equation: $\mathrm{SR}=$ (number of females) / (number of females + number of males); number of female offspring produced per female for the next generation $\left(\mathrm{M}_{\mathrm{x}}\right)$; cumulative survival rate up to age $\mathrm{X}\left(\mathrm{L}_{\mathrm{x}}\right)$; net reproductive rate $\left(\mathrm{R}_{\mathrm{o}}\right)$; gross reproduction rate (TBR); intrinsic rate of natural increase $(\mathrm{r})$; intrinsic increase rate $\left(\mathrm{R}_{\mathrm{m}}\right)$; finite rate of population increase $(\lambda)$; estimating the interval between generation time (T) in days; and population doubling time $(\mathrm{Td})$ in days. The data were processed using the program SigmaPlot14.

\section{Results and Discussion}

T. giffardianus females began parasitism in $C$. capitata larvae in the first $24 \mathrm{~h}$ after emergence, indicating that this parasitoid does not have a pre-oviposition period, with ovarian maturation occurring in the pupal period and in early adulthood (PEMBERTON; WILLARD, 1918). The mean number of offspring per female during their lifetime was 75.6, with the maximum parasitism occurring on the first day (Figure 2). The high number of offspring on the first day of host exposure may have been potentiated by the group effect, because some species of parasitoids exhibit distinct biological parameters when analyzed in group (ALUJA et al., 2009) or separated into couples (GONÇALVES et al., 2016).

Figure 2. Fertility dynamics of a population of Tetrastichus giffardianus parasitizing Ceratitis capitata larvae under laboratory conditions (temperature: $25 \pm 2^{\circ} \mathrm{C}$; relative humidity: $60 \pm 10 \%$; $12 \mathrm{~h}$ photophase).

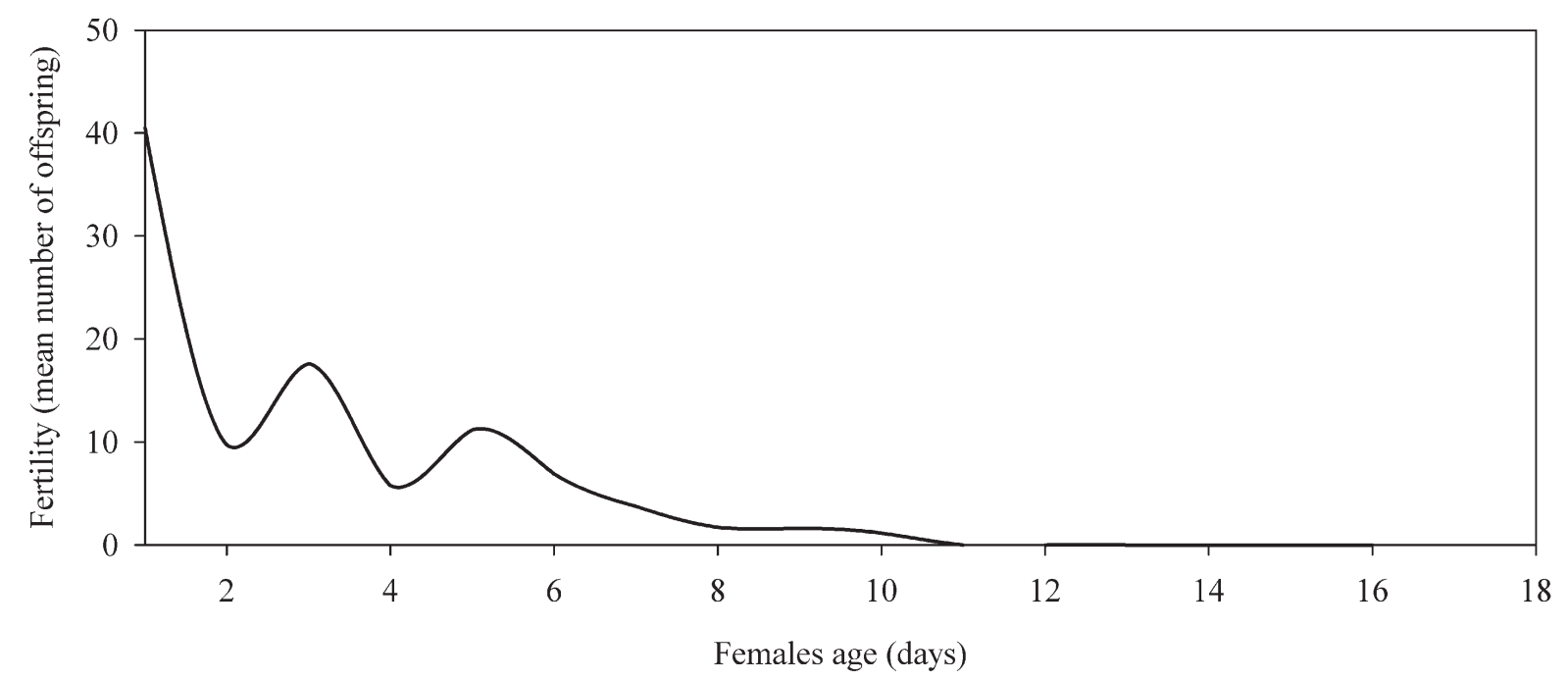

Some adults survived until the 16th day, but 50\% of the population died before the 10th day (Figure 3). The longevity of individuals in the population was superior to the longevity reported by Purcell et al. (1996), which was 10.1 days for females. These results indicate that the effects of the group on longevity in $T$. giffardianus require further evaluation.
The sex ratio (SR) of emerged parasitoids was significantly biased to females (0.74). This reproductive trait is common in other species of the genus Tetrastichus (PEMBERTON; WILLARD, 1918). In biological control, the use of parasitoids with an SR that optimizes the production of females is important for controlling pests in the field because females carry out the parasitism. 
The demographic parameters obtained in this study included a $\mathrm{R}_{\mathrm{o}}$ value 54.93 of $T$. giffardianus. This value indicates that each female of the population contributed 54.93 female progeny for the next generation (Table 1). Purcell et al. (1996) reported the slightly lower value of 42.6 female progeny per day for $T$. giffardianus, reared in $C$. capitata six-day larvae. The highest net reproductive rate obtained in our study may have been influenced by the size and age of the $C$. capitata larvae used ( \pm 10 days), larger larvae may provide the development of a larger number of parasitoids.
The $\mathrm{R}_{\mathrm{o}}$ for $T$. giffardianus observed was higher than the rate of 45.56 reported for the parasitoid Diachasmimorpha longicaudata (Ashmead) (Hymenoptera: Braconidae) (MEIRELLES et al., 2013) and 2.60 for Aganaspis pelleranoi (Brèthes) (Hymenoptera: Figitidae) (GONÇALVES et al., 2013), reared in C. capitata larvae. T. giffardianus parasitized a smaller number of larvae per day than D. longicaudata (NÚÑEZ-CAMPERO et al., 2016; SUAREZ et al., 2014). However, this is offset by the gregarious habit and tendentious sex ratio for females in T. giffardianus.

Figure 3. Survival of a population of Tetrastichus giffardianus parasitizing Ceratitis capitata larvae under laboratory conditions (temperature: $25 \pm 2{ }^{\circ} \mathrm{C}$; relative humidity: $60 \pm 10 \% ; 12 \mathrm{~h}$ photophase).

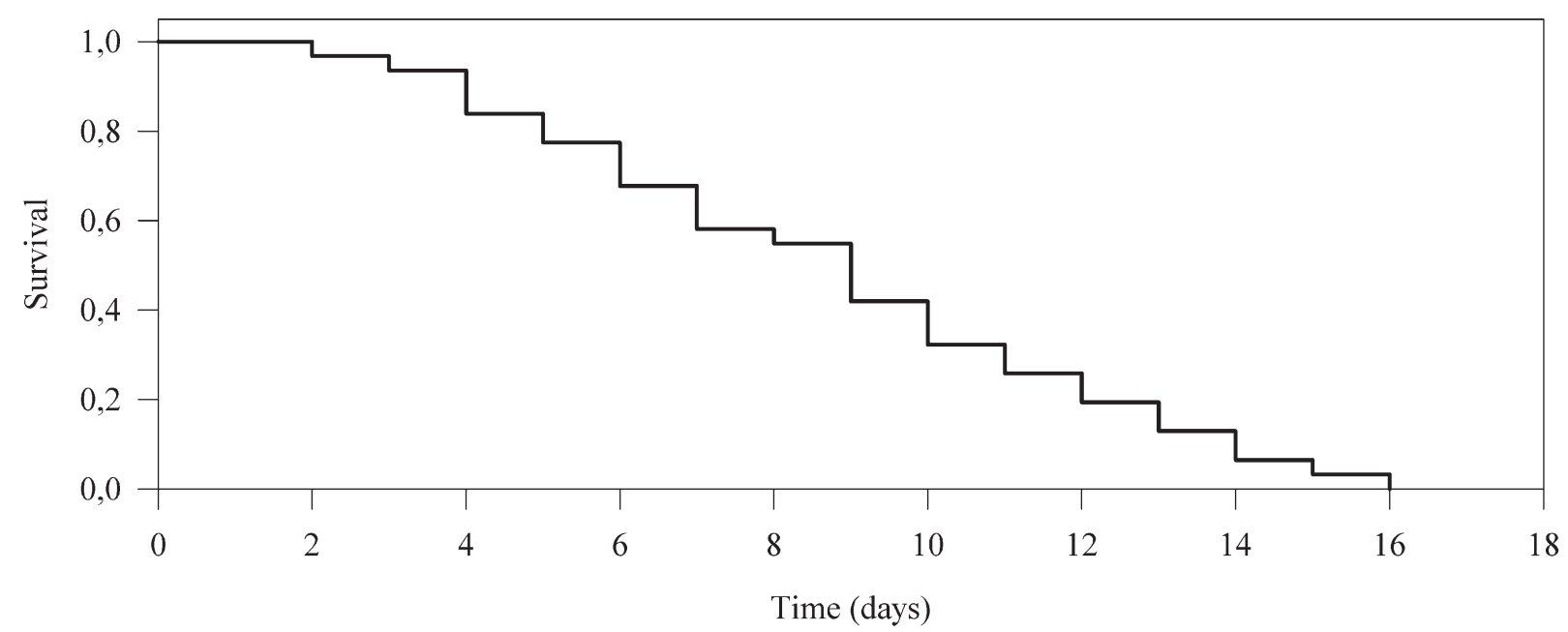

Table 1. Average values of demographic parameters for a Tetrastichus giffardianus population, reared in larvae of Ceratitis capitata.

\begin{tabular}{lcc}
\hline \multicolumn{1}{c}{ Demographic parameters } & Calculation & Value \\
\hline Net reproductive rate $\left(\mathrm{R}_{\mathrm{o}}\right)$ & $\Sigma \mathrm{Mx} . \mathrm{lx}$ & $54.93 \pm 3.04$ \\
Intrinsic rate of increase $\left(\mathrm{R}_{\mathrm{m}}\right)$ & $\mathrm{Ln}(\mathrm{Ro} / \mathrm{T})$ & $0.34 \pm 0.03$ \\
Interval between generation time $(\mathrm{T})$ (days) & $\Sigma \mathrm{x} . \mathrm{lx} . \mathrm{Mx} / \Sigma \mathrm{Mx} . \mathrm{x}$ & $19.70 \pm 0.16$ \\
Population doubling time $(\mathrm{Td})$ (days) & $\mathrm{In} 2 / \mathrm{r}$ & $2.03 \pm 0.04$ \\
Finite rate of population increase $(\lambda)$ & $e^{r}$ & $1.41 \pm 0.06$ \\
\hline
\end{tabular}


The $\mathrm{R}_{\mathrm{m}}$ value for T. giffardianus was 0.34 (Table 1). This ratio was higher than in other species of fruit fly parasitoids, such as $D$. longicaudata $\left(\mathrm{R}_{\mathrm{m}}=0.14\right)$ (MEIRELLES et al., 2013) and A. pelleranoi $\left(\mathrm{R}_{\mathrm{m}}\right.$ $=0.02$ ) (GONÇALVES et al., 2016). However, it was smaller than the egg parasitoid Fopius arisanus (Sonan) (Hymenoptera: Braconidae) $\left(\mathrm{R}_{\mathrm{m}}=0.39\right)$ (GROTH et al., 2016). According to Pedigo and Zeiss (1996), a larger value of $R_{m}$ indicates better adaptation of the species to a particular environment or host.

The $\mathrm{T}$ value for $T$. giffardianus was 19.7 days and the Td was 2.03 days (Table 1). These values are similar to those reported by Purcell et al. (1996), namely $\mathrm{T}$ of 21.09 days and $\mathrm{Td}$ of 3.9 days for $T$. giffardianus. The lowest $\mathrm{Td}$ (2.03 days) recorded in this study may be related to the age of the larvae used as host for T. giffardianus (third instar larvae \pm 10 days), in contrast to the six-day-old larvae used by Purcell et al. (1996). Larger larvae are able to provide a greater amount of food for the parasitoids, directly influencing the increase in reproductive potential of the population. The $\lambda$ value was 1.41 , showing that each day the population increased 1.41 fold.

The results obtained in this study can contribute to the rearing of $T$. giffardianus in order to conduct basic and applied studies, with the aim of using this parasitoid in the biological control of C. capitata.

\section{Conclusion}

The results demonstrate that the rearing technique used can be employed to rear $T$. giffardianus populations under laboratory conditions (temperature: $25 \pm 2^{\circ} \mathrm{C}$; relative humidity: $60 \pm$ $10 \% ; 12 \mathrm{~h}$ photophase).

The average values of the demographic parameters indicate that this methodology allows the continuous increase in the $T$. giffardianus population, reared in C. capitata larvae.

\section{Acknowledgment}

We are grateful to the Coordination for the Improvement of Higher Education Personnel (CAPES) for granting the doctoral scholarship to the first author, and Dr. Valmir Antônio Costa, Agência Paulista de Tecnologia dos Agronegócios (APTA) for the identification of $T$. giffardianus parasitoid. Thanks to the National Council for Scientific and Technological Development (CNPq) for granting a research scholarship to author Elton L. Araujo.

\section{References}

ALUJA, M.; SIVINSKI, J.; OVRUSKI, S.; GUILLÉN, L.; LÓPEZ, M.; CANCINO, J.; TORRES-ANAYA, A.; GALLEGOS-CHAN, G.; RUÍZ, L. Colonization and domestication of seven species of native New World hymenopterous larval-prepupal and pupal fruit fly (Diptera: Tephritidae) parasitoids. Biocontrol Science and Technology, v. 19, n. 1, p. 49-79, 2009. DOI: 10.1080/09583150802377373

ARAÚJO, A. A. R.; SILVA, P. R. R.; SILVA, R. B. Q.; SOUSA, E. P. D. S. Tetrastichus giffardianus on pupae of Anastrepha in Brazil. Ciência Rural, Santa Maria, v. 46, n. 7, p. 1134-1135, 2016. DOI: 10.1590/01038478 cr20150890

ARAUJO, E. L.; FERNANDES, E. C.; SILVA, R. I. R.; FERREIRA, A. D. C. L.; COSTA, V. A. Parasitoides (Hymenoptera) de moscas-das-frutas (Diptera: Tephritidae) no semiárido do estado do Ceará, Brasil. Revista Brasileira de Fruticultura, Jaboticabal, v. 37, n. 3, p. 610-616, 2015. DOI: 10.1590/0100-2945-188/14.

ARAUJO, E. L.; RIBEIRO, J. C.; CHAGAS, M. C. M.; DUTRA, V. S.; SILVA, J. G. Moscas-das-frutas (Diptera: Tephritidae) em um pomar de goiabeira, no semiárido brasileiro. Revista Brasileira de Fruticultura, Jaboticabal, v. 35, n. 2, p. 41-51, 2013. DOI: 10.1590/ S0100-29452013000200016.

CANCINO, J.; RUIZ, L.; SIVINSKI, J.; GALVEZ, F. O.; ALUJA, M. Rearing of 5 hymenopterous larval prepupal (Braconidae, Figitidae) and three pupal (Diapriidae, Chalcidoidea, Eurytomidae) native parasitoids of the genus Anastrepha (Diptera: Tephritidae) on irradiated A. ludens larvae and pupae. Biocontrol Science and Technology, v. 19, n. 1, p. 193-209, 2009. DOI: $10.1080 / 09583150802377423$ 
COSTA, V. A.; ARAUJO, E. L.; GUIMARÃES, J. A.; NASCIMENTO, A. S.; LASALLE, J. Redescoberta de Tetrastichus giffardianus (Hymenoptera: Eulophidae) após 60 anos da sua introdução no Brasil. Arquivo do Instituto Biológico, São Paulo, v. 4, n. 72, p. 539-541, 2005. DOI: $10.1590 / 0103-8478$ cr20150890

GONÇALVES, R. S.; ANDREAZZA, F.; LISBÔA, H.; GRÜTZMACHER, A. D.; VALGAS, R. A.; MANICABERTO, R.; NÖRNBERG, S. D.; NAVA, D. E. Basis for the development of a rearing technique of Aganaspis pelleranoi (Hymenoptera: Figitidae) in Anastrepha fraterculus (Tephritidae: Diptera). Journal of Economic Entomology, Riverside, v. 109, n. 3, p. 1094-1101, 2016. DOI: $10.1093 /$ jee/tow069

GONÇALVES, R. S.; NAVA, D. E.; PEREIRA, H. C.; LISBOA, H.; GRUTZMACHER, D. D.; VALGAS, R. A. Biology and fertility life table of Aganaspis pelleranoi (Hymenoptera: Figitidae) in larvae of Anastrepha fraterculus and Ceratitis capitata (Diptera: Tephritidae). Annals of the Entomological Society of America, Annapolis, v. 106, n. 6, p. 791-798, 2013. DOI: 10.1603/ AN13044

GROTH, M. Z.; LOECK, A. E.; NORNBERG, S. D.; BERNARDI, D.; NAVA, D. E. Biology of Fopius arisanus (Hymenoptera: Braconidae) in two species of fruit flies. Journal of Insect Science, Annapolis, v. 16, n. 1, p. 1-7, 2016. DOI:10.1093/jisesa/iew087

MEIRELLES, R. N.; REDAELLI, L. R.; OURIQUE, C. B. Comparative biology of Diachasmimorpha longicaudata (Hymenoptera: Braconidae) reared on Anastrepha fraterculus and Ceratitis capitata (Diptera: Tephritidae). Florida Entomologist, Washington, v. 96, n. 2, p. 412-418, 2013. DOI: 10.1653/024.096.0204

NÚÑEZ-CAMPERO, S. R.; BENITEZ-VIEYRA, S.; GORLA, D. E.; OVRUSKI, S. M. Changes in Diachasmimorpha longicaudata (Hymenoptera: Braconidae) functional response as consequence of host density choice. Annals of the Entomological Society of America, Washington, v. 109, n. 5, p. 730-736, 2016. DOI: $10.1653 / 024.096 .0204$
OVRUSKI, S.; ALUJA, M.; SIVINSKI, J.; WHARTON, R. Hymenopteran parasitoids on fruit-infesting Tephritidae (Diptera) in Latin America and the southern United States: diversity, distribution, taxonomic status and their use in fruit fly biological control. Integrated Pest Management Reviews, v. 5, n. 2, p. 81-107, 2000. DOI: 10.1023/A:1009652431251

PARRA, J. R. P. Biological Control in Brazil: an overview. Scientia Agricola, Piracicaba, v. 71, n. 5, p. 345-355, 2014. DOI: 10.1590/0103-9016-2014-0167

PEDIGO, L. P.; ZEISS, R. M. Constructing life table for insect populations. In: PEDIGO, L. P.; ZEISS, R. M. Analyses in insect ecology and management. Iowa: Iowa State University Press, 1996. p. 75-105.

PEMBERTON, C. E.; WILLARD, H. F. A contribution to the biology of fruit-fly parasites in Hawaii. Journal of Agricultural Research, Washington, v. 15, n. 8, p. 419$465,1918$.

PURCELL, M. F.; NIEUWENHOVEN, A. V.; BATCHELOR, M. A. Bionomics of Tetrastichus giffardianus (Hymenoptera: Eulophidae): an endoparasitoid of tephritid fruit flies. Environmental Entomology, College Park, v. 25, n. 1, p. 198-206, 1996. DOI: $10.1093 /$ ee/25.1.198

SILVEIRA NETO, S.; NAKANO, O.; BARBIN, D.; VILLA NOVA, N. A. Manual de ecologia de insetos. São Paulo: Agronômica Ceres, 1976. 419 p.

SUAREZ, L.; MURUA, F.; LARA, N.; ESCOBAR, J.; TARET, G.; RUBIO, J. L.; NIEUWENHOVE, G. V., BEZDJIAN, L.; SCHLISERMAN, P.; OVRUSKI, S. M. Biological control of Ceratitis capitata (Diptera: Tephritidae) in Argentina: releases of Diachasmimorpha longicaudata (Hymenoptera: Braconidae) in fruitproducing semi-arid areas of San Juan. Natural Science, v. 6 , n. 9 , p. $664-675$, 2014. DOI: 10.4236/ns.2014.69066

ZUCCHI, R. A. Fruit flies in Brazil: hosts and parasitoids of the Mediterranean fruit fly. Piracicaba: ESALQ, 2012. Available at: www.lea.esalq.usp.br/ceratitis/. Accessed at: 18 jan. 2018. 